\section{A VISÃO DOS GESTORES PÚBLICOS SOBRE O PAPEL DA CONAB NA GESTÃO DOS ESTOQUES DE ALIMENTOS NO PERÍODO DE 2003 A 2014}

Marcelo Botton Piccin ${ }^{1}$

Newton Narciso Gomes Junior

RESUMO: O artigo analisa o papel desempenhado pela Companhia Nacional de Abastecimento (CONAB) na gestão dos estoques públicos de alimentos, executados através da Política de Garantia de Preços Mínimos (PGPM) e do Programa de Aquisição de Alimentos (PAA), no período de 2003 a 2014, sob a perspectiva da promoção do direito humano à alimentação adequada (DHAA) e da soberania alimentar. As evidências analisadas indicam que a Conab cumpriu um duplo papel: a) fortaleceu o histórico sistema agroalimentar exportador de alimentos; e b) possibilitou, pela primeira vez, o acesso da agricultura familiar a importantes políticas públicas, mesmo sendo essas de dimensão ainda insuficientes e comparativamente subalternas às acessadas pelo agronegócio. A PGPM, manteve sua lógica histórica: atrelada aos mecanismos do mercado privado, baixa formação de estoques públicos, com atuação pontual e fragmentada, pouca incidência no controle da inflação e na estabilização dos preços. Já o PAA mostra-se como um programa estruturador, alinhado aos princípios do DHAA e à soberania alimentar. As evidências também apontam para a inexistência de uma política nacional de abastecimento que supere a transferência de renda como mecanismo principal de acesso.

Palavras-Chave: Abastecimento, Estoques públicos de alimentos, Segurança alimentar e nutricional, Combate à fome.

\footnotetext{
Mestre em Agroecossitemas pela UFSC (2017) e Membro do Grupo de Pesquisa Mercados\&Comidas do Núcleo de Estudos das Políticas de Abastecimento Alimentar e Segurança Alimentar e Nutricional, da Universidade de Brasília.

2Professor Adjunto do Departamento de Serviço Social da Universidade de Brasília; Coordenador do Diretório de Pesquisa Mercados\&Comida UnB/CNPQ; Especialista em Abastecimento Alimentar e Desenvolvimento

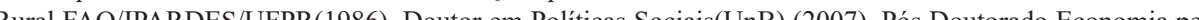
Re Instituto de Econonia da Universidade de Canphas UNICAMPArea de concentraça Politicas Públicas Segurança Alimentar e Nutricional, Sistemas de Abastecimento Alimentar, Questão Agrária e Desenvolvimento Rural, Necessidades Humanas Básicas e Cidadania.
}

ABSTRACT: The article analyses the role developed by the National Supply Company (CONAB) in the management of food stocks, carried out throughout the Minimum Price Guarantee Policy (PGPM) and the Food Acquisition Program (PAA), in the period of 2003 to 2004, from the perspective of the human right promotion to adequate food (DHAA) and food sovereignty. The analysed evidences indicate that CONAB fulfilled two roles: a) it strengthened the historic exporting agrifood system; and b) it enabled, for the first time, the access of family farming to important public policies, even those being insufficient and comparatively subalterns to those accessed by the agribusiness. The PGPM kept its historic logic: it is attached to the private market mechanisms, low composition of public stocks, with punctual and fragmented practices, low incidence into the control of inflation and stabilisation of prices. Thus, the PAA show itself as a structuring programme, aligned with the principles of DHAA and food sovereignty. The evidences also point to the non-existence of a national supply policy that can replace cash transference as the main mechanism of access.

KeYwords: Food Supply; Food Public Stock; Food And Nutritional Security; Fight Against Hunger.

\section{INTRODUÇão}

Ao longo da história da humanidade, a formação de estoques reguladores de alimentos, conformaram as primeiras políticas públicas adotadas pelas nações como mecanismos atenuantes das oscilações de preços e de garantia estratégica de reservas na perspectiva de se precaver do flagelo da fome. Mais recentemente, a partir das duas grandes guerras mundiais, ocorridas no século XX, foram instituídos os mecanismos de formação de estoques públicos de alimentos, com intuito de estabilização dos preços, da regulação da oferta, procurando aferir maior regulação do mercado de commodities agrícolas, de modo a evitar crises alimentares.

Analisar a atuação dos estoques de alimentos, especialmente os formados pelo poder público, tem se constituído numa questão importante para a agenda de promoção da segurança alimentar e nutricional nacional e internacional, ganhando cada vez mais espaço nos governos, órgãos internacionais e organizações da sociedade civil.

Após a liberalização e desregulamentação dos mercados alimentares, ocorridas em grande parte dos países, entre as décadas 1970 e 1990, 
muitas nações abriram mão dos mecanismos de formação de estoques públicos de alimentos como instrumentos de estabilização dos mercados e de promoção do abastecimento, delegando essas atribuições ao mercado privado (DELGADO, 1995, 2005).

A crise econômica e a elevação internacional dos preços das commodities agrícolas, ocorrida especialmente a partir dos anos de 2008 e 2009, provocaram diferentes impactos no acesso aos alimentos pelas populações latino-americanas e propuseram a reflexão sobre a gestão dos estoques públicos de alimentos e seu papel estratégico para a promoção da Segurança Alimentar e Nutricional, para a garantia do direito à alimentação e para a promoção da soberania alimentar ${ }^{3}$ das nações (ALADI; FAO, 2015).

$\mathrm{Na}$ América Latina e Caribe, a Comunidade dos Estados Latinoamericanos e Caribenhos (CELAC) apresentou, em 2014, um Plano para a Segurança Alimentar e Nutricional e Erradicação da Fome 2025. O plano propõe uma política comercial intra-regional de alimentos com intuito de contribuir com a erradicação da fome e da miséria no continente. Dentre as propostas a serem implementadas, está a criação de um programa latino-americano de reservas e estoques de alimentos, formado a partir da produção da agricultura familiar e direcionado, inicialmente, à prevenção de catástrofes socioambientais, bem como à formação de reservas no interior da região para outros casos de necessidade (CELAC, 2014).

$\mathrm{O}$ Brasil tem enfrentado crises frequentes de abastecimento alimentar ao longo de sua história. Parte expressiva da população permaneceu, por vários séculos, sob a condição de extrema pobreza e assolada pela fome e pela desnutrição. Tal fenômeno tem sido apontado como resultante da adoção, pelo Estado brasileiro, de uma política econômica dependente e um sistema agroalimentar pautado na exportação de alimentos, em detrimento da produção para o abastecimento interno.

Existem diversos entendimentos sobre o conceito de soberania alimentar. O entendimento adotado neste estudo é o definido pela Lei Orgânica de Segurança Alimentar e Nutricional - LOSAN, onde em seu Art. $5^{\circ}$ define: "A consecução do direito humano à alimentação e da segurança alimentar e nutricional requer o respeito à soberania que confere aos países a primazia de suas decisões sobre a produção e o consumo de alimentos". Em complementação a este entendimento, também adotamos o conceito definido pela Via Campesina: "soberania alimentar é o direito dos povos em definir suas próprias políticas e estratégias sustentáveis de produção, distribuição e consumo de alimentos, que garantam o direito à alimentação a toda a população, com base na pequena e média producão, respeitando suas próprias culturas e a diversidade dos modos camponeses de

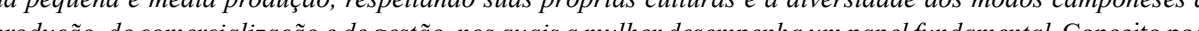

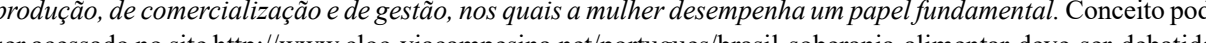
ser acessado no site http://www.cloc-viacampesina.net/portugues/brasil-soberania-alimentar-deve-ser-debatidapelo-conjunto-da-sociedade. Acesso em 12/07/2018.
Tais fatos e evidências repuseram a questão dos estoques de alimentos privados e/ou públicos na ordem do dia dos governos e da sociedade. Como veremos durante o estudo, as lógicas que dirigem as políticas públicas de formação de estoques públicos de alimentos podem contribuir ou não para a promoção do direito humano à alimentação e a soberania alimentar, definidos como princípios norteadores da Lei Orgânica de Segurança Alimentar e Nutricional - LOSAN e firmados no artigo $6^{\circ}$ da Constituição Federal.

No Brasil, os estoques públicos de alimentos são formados através da Política de Garantia de Preços Mínimos (PGPM) ${ }^{4}$ e pelo Programa de Aquisição de Alimentos (PAA) ${ }^{5}$, ambos geridos e executados pela $\mathrm{CONAB}^{6}$.

Este artigo baseou-se em pesquisa documental, análise de fontes e dados secundários, bem como entrevistas semiestruturadas realizadas com atores-chave relacionados à gestão pública federal, que se envolveram na concepção, execução, monitoramento e avaliação das políticas agrícolas, de abastecimento, de agricultura familiar e de segurança alimentar e nutricional, durante o período analisado.

${ }^{4}$ A PGPM é executada desde 1943, através da instituição da Companhia de Financiamento da Produção (CFP), criada pelo Decreto-Lei ${ }^{\circ} 5.212$, de 21 de janeiro de 1943, e tinha como objetivos: a) adquirir produtos pelo preço mínimo fixado; b) conceder financiamento, com ou sem opção de venda, inclusive para beneficiamento, acondicionamento e transporte dos produtos amparados pela PGPM; c) vender produtos adquiridos na form do item anterior; d) formar estoques reguladores; e) importar e exportar produtos especialmente indicados pelo Conselho Monet́rio Nacionl. Atualmente os principais instrumentos du PGPM são: Aquisica do Governo Federal-AGF; Co do Escoan Valor de Referência da Soja-PESOJA; Prêmio de Risco para Aquisição de Produto Agrícola Oriundo de Contrato Privado de Opção de Venda - PROP- e Contrato Privado de Opção de Venda - CPOV. AAGF e o CPOV formam estoques públicos de alimentos e os demais mecanismos viabilizam a comercialização privada.

${ }^{5}$ Sob a luz da estratégia Fome Zero, anunciada pelo Governo Lula em 2003, com o intuito de estruturar ações no âmbito da política agrícola e agrária e da segurança alimentar, dando concretude às diretrizes apresentada pelo Grupo Técnico Interministerial e Grupo Técnico do CONSEA criados para estruturar os ańncios do Plano

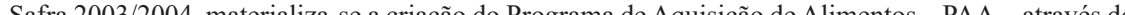

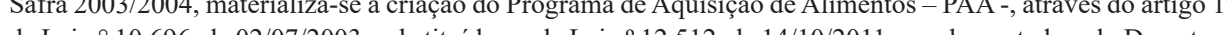
7.775 , de $04 / 07 / 2012$, e,

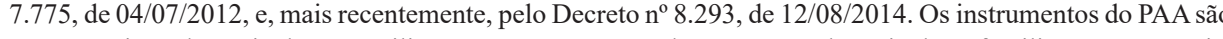
Compra Direta da Agricultura Familiar - CDAF; Formação de Estoques pela agricultura familiar - FE; Incentivo à produção e consumo de leite - PAA leite; Compra com doação simultânea - CDS; Compra Institucional - CI e Aquisição de Sementes - PAA - sementes. Os recursos são alocados no Ministério de Desenvolvimento Social e na Secretaria Especial de agricultura familiar e do desenvolvimento agrário. Os estoques públicos são formados pela modalidade $\mathrm{CDAF}$ e os estoques provados pela $\mathrm{FE}$.

${ }^{6}$ A Companhia Nacional do Abastecimento - CONAB, empresa pública vinculada ao Ministério da Agricultura, Pecuária e Abastecimento, foi instituída por meio da Medida Provisória n ${ }^{\circ} 151$, de 15/03/1990, transformada na Lei n. ${ }^{\circ} 8.029$, de 12 de abril de 1990, que autorizou a fusão da CFP, criada em 1945, da COBAL - Companhia Brasileira de Alimentos -, Empresa Pública Federal e da CIBRAZEM - Companhia Brasileira de Armazenamento, criadas em 1962. O Decreto n ${ }^{\circ} 99.233$, de 03/05/1990, estabeleceu os procedimentos preparatórios ao processo de fusão. Pode ser acessada <http://www.CONAB.gov.br/CONAB-quemSomos.php>. Acessado em 29/03/2017 
O objetivo é analisar o papel desempenhado pela CONAB em relação ao cumprimento de sua missão ${ }^{7}$ institucional definida como orientadora de sua ação no período de 2003 a 2014, bem como as lógicas e perspectivas que orientaram a execução da PGPM e do PAA pela empresa neste período.

\section{EXeCuÇão da PGPM e do PAA: ALGUNS dAdos Gerais}

De acordo com a CONAB, no período de 1999 a 2015, os gastos nominais do governo com a PGPM nos produtos arroz, milho e trigo, chegaram a um acumulado de R $\$ 20,6$ bilhões. Deste montante, R $\$ 13,5$ bilhões foram usados na formação de estoques (AGF e COV) e R \$ 7,1 bilhões na subvenção a comercialização (PEP, PROP, PEPRO). Nesse período, as receitas nominais, realizadas com a comercialização dos estoques governamentais, com o intuito de equilibrar preços internos, chegaram na marca de $\mathrm{R} \$ 11,9$ bilhões (CONAB, 2016)

Gráfico 1: Recursos aplicados e receitas da PGPM, de 1999 a 2015.

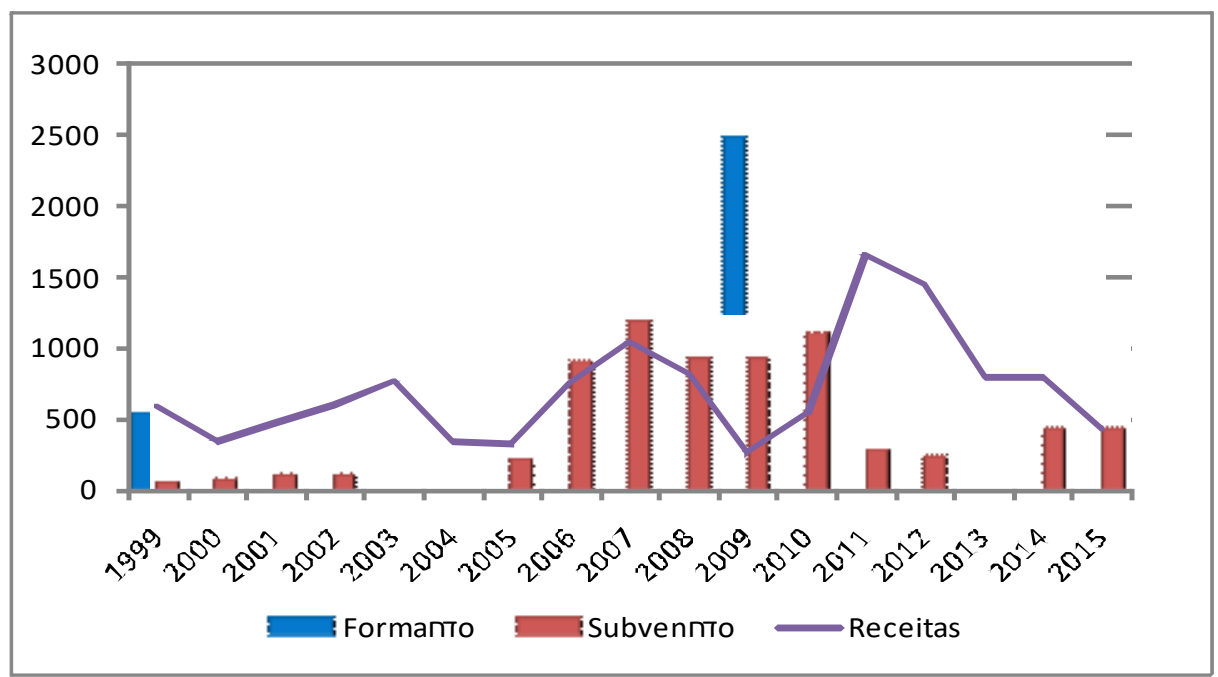

Fonte: CONAB, 2016.

Das 108 milhões de toneladas de produtos mobilizadas no período de

${ }^{7}$ Missão da CONAB definida em 2003 que permanece atualmente: "Promover a garantia de renda ao produtor rural, a segurança alimentar e nutricional e a regularidade do abastecimento, gerando inteligência para a agropecuária e participando da formulação e execução das políticas públicas").
2003 a $2015^{8}$, por meio de todos os mecanismos da PGPM, 104,2 milhões foram constituídas com algodão, soja, trigo, arroz e milho, conforme demonstrado no gráfico 2 .

Gráfico 2- Execução da PGPM para as culturas do milho, soja, trigo, arroz e algodão, de 2003 a 2015.

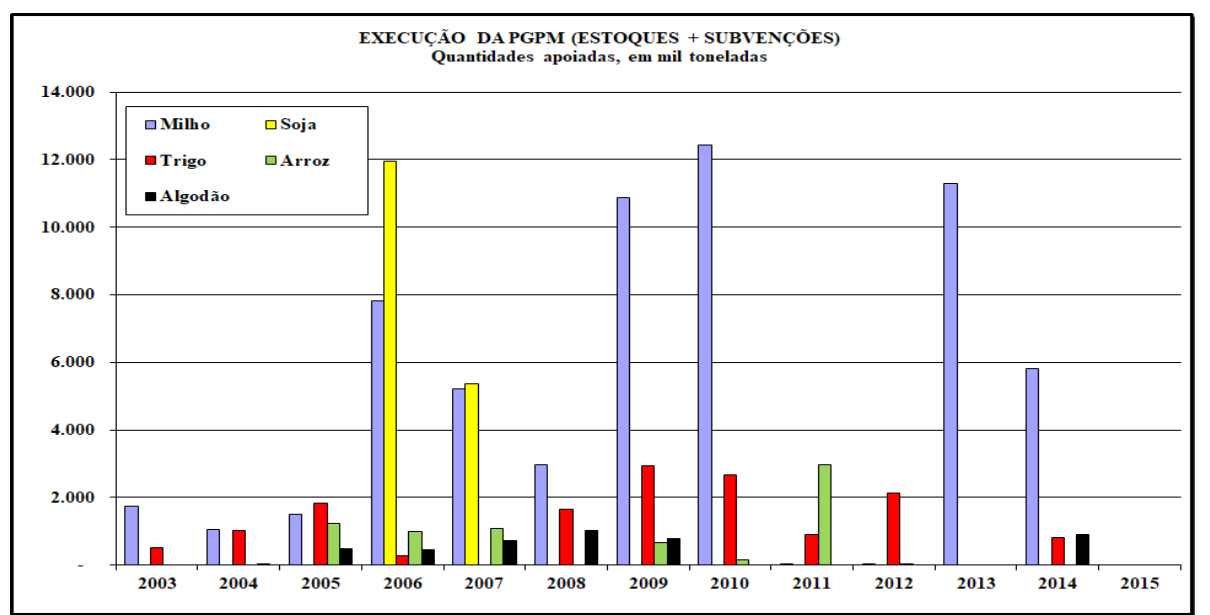

Fonte: Mapa/SPA e CONAB 2017.

Já o PAA, constituiu-se como um dos principais programas criados pela Estratégia Fome Zero e um dos principais anúncios do Plano Safra para a Agricultura Familiar 2003/2004. ${ }^{9}$

Segundo dados do Governo Federal ${ }^{10}$ (2015), no período de 2003 a 2015, foi investido cerca de R $\$ 6,4$ bilhões em alimentos oriundos da agricultura familiar, envolvendo, diretamente, em torno de 150 mil famílias ao ano.

\footnotetext{
${ }^{3}$ Todos os dados de execucão da PGPM referentes ao período estão disponibilizados no relatório de séries históricas, fornecido pelo MAPA, e um monitoramento de execução física e financeira para os seguintes produtos: algodão, arroz, borracha, café, feijão, mandioca, milho, sisal, soja, semente de soja, sorgo, trigo, vinho, laranja, uva e leite de vaca. O relatório pode ser acessado no site $<$ http://www.agricultura.gov.br/assuntos/politicaagricola/todas-publicacoes-de-politica-agricola/sumarios-executivos-de-produtos-agricolas/ano-civil-apoio-acomercializacao-2003-2018-abril-2018.pdf> Acesso realizado em 12/07/2018.

${ }^{9}$ Segundo Delgado (2005), a concepção original do Projeto Fome Zero, assumida pelas Diretrizes do Plano de Safra e normatizada pelo PAA, de forma específica, compreende três objetivos, correspondentes a três funçõe distintas de política pública: i) de constituição de um polo institucional de demanda por alimentos dirigido a alimentar-nut segurança alimentar. (DELGADO, 2005, p.20).

${ }^{10}$ Dados apresentados na reunião do Grupo Gestor do PAA, realizada em 11 de março de 2016/Brasília/ DF
} 
Foram mais de 4,6 milhões de toneladas de alimentos adquiridos, que abasteceram uma rede nacional de proteção e promoção social, composta por mais de 20 mil instituições que atenderam milhões de pessoas em situação de vulnerabilidade social, em mais de 3.200 municípios brasileiros.

No gráfico 3, podemos analisar o comportamento do montante dos recursos executados pelo PAA, no período de 2003 a 2015, a partir dos instrumentos de parceria que regularam a execução do MDS e do MDA com a CONAB e demais entes federativos.

Gráfico 3 - Evolução da execução dos recursos do PAA, por instrumentos de parceria utilizados pelo MDS e MDA, de 2003 a 2015 (milhões de R\$).

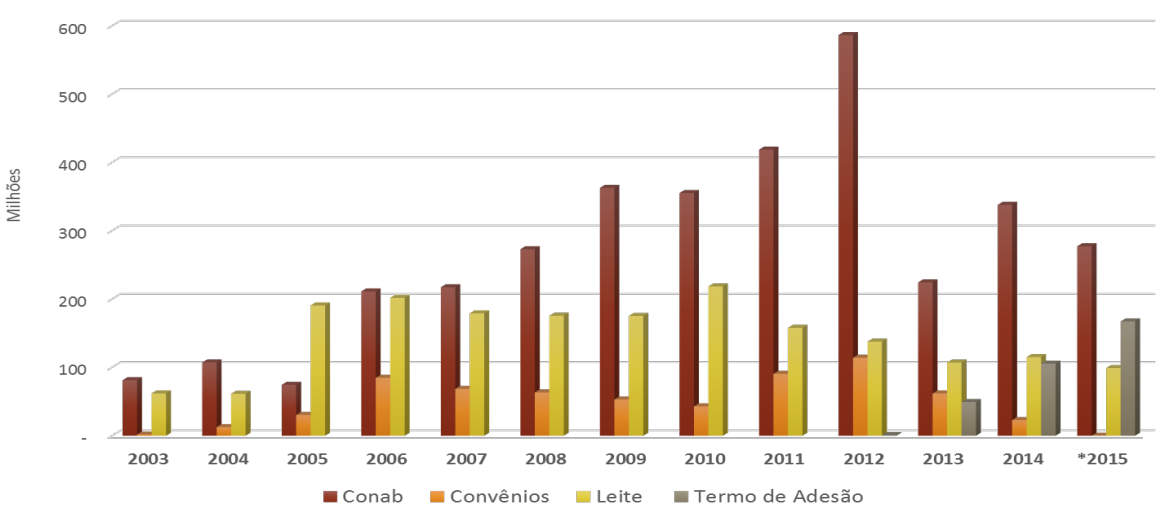

Fonte: MDS, 2016. Relatório apresentado na reunião do Grupo Gestor do PAA, em $25 / 02 / 16$

É possível observar a diversidade de executores e instrumentos de execução adotados no período. De maneira geral, os recursos executados pela CONAB foram fruto das cooperações realizadas entre a empresa e os Ministérios do Desenvolvimento Social e do Desenvolvimento Agrário. Esse formato se refere à execução centralizada do PAA pelo Governo Federal, através das modalidades instituídas pela CONAB ao longo do período estudado. Já nos convênios, a modalidade PAA leite e os termos de adesão são todos instrumentos executados pelo Ministério do Desenvolvimento Social com o Distrito Federal, estados e municípios e referem-se ao PAA leite e PAA doação simultânea. A execução do PAA compra institucional não faz parte da análise por ser executado com recursos próprios de cada órgão.
Dos recursos totais do PAA executados pela CONAB no período de 2003 a 2016, que somaram R \$3,7 bilhões de reais, a modalidade Doação Simultânea foi responsável por $67,5 \%$ dos recursos, ou seja, R $\$ 2,5$ bilhões. No entanto, nosso foco é analisar e compreender a execução e gestão das outras modalidades que constituem os estoques públicos de alimentos, compostos pelo PAA-CDAF e PAA-FE, geridas pelo MDS e MDA e executadas pela CONAB, por meio de cooperação, conforme gráfico 4 .

Gráfico 4 - Evolução da execução financeira do PAA, executado pela CONAB, modalidades FE e CDAF, vinculadas ao MDA e MDS, de 2003 a 2016.

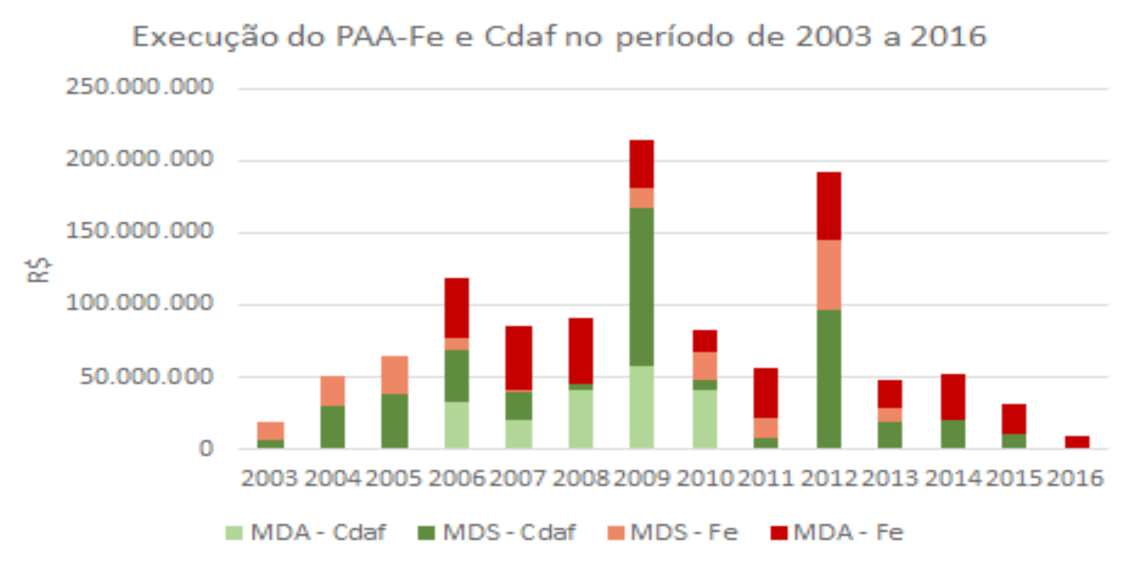

Fonte: CONAB, 2017

De maneira geral, é possível afirmar que a dinâmica de execução, realizada pelo MDA, MDS e CONAB, na composição das duas modalidades, teve um esforço de combinar a execução financeira entre os ministérios, especialmente no PAA-CDAF, que priorizou sua atuação em produtos que formavam a cesta de alimentos, distribuídas às populações vulneráveis, tais como: arroz, feijão, farinha de mandioca, farinha de trigo e leite em pó. Produtos clássicos dos sistemas produtivos das agriculturas de base familiar e componentes estruturais da cesta de alimentos. Outros produtos são pontualmente identificados na atuação do PAA-CDAF, ao longo do período estudado, como sucos e doces. Nesses, houve claramente, uma intervenção no mercado pela $\mathrm{CONAB}$, no sentido de garantir o nível de renda aos agricultores familiares, tendo uma atuação semelhante à do AGF da PGPM. Esses produtos também formaram estoques públicos e foram 
direcionados ao abastecimento dos programas sociais de segurança alimentar no país, muitos deles, vinculados às esferas municipais, com forte atuação da política de assistência social.

Já o PAA-FE atuou em duas frentes: a primeira, articulada à formação de estoques para composição, também, das cestas de alimentos, reforçando a conexão entre as modalidades em sua atuação nos mesmos produtos com a mesma finalidade, e, numa segunda, composta por um conjunto mais amplo de alimentos, especialmente processados, grãos e oleaginosas, lácteos, castanhas e sementes. Por trabalhar na perspectiva do fortalecimento do processo de transformação dos alimentos para agregar mais valor e possibilitar melhores alternativas de comercialização, cumpriu um papel importante na garantia de renda aos agricultores, além de promover o abastecimento local sem a necessidade de transformar toda a aquisição em estoques públicos. Segundo documentos do MDA, em 2015, outros programas complementares deveriam ser melhor estruturados para viabilizarem uma melhor gestão pelas Cooperativas e Associações desta modalidade do PAA, como por exemplo: assessoria permanente em gestão e acesso a novas linhas de capital de giro. Nesta perspectiva, o MDA lança no plano safra de 2015/2016, o Programa Nacional de Fortalecimento do Cooperativismo e Associativismo Solidário da Agricultura Familiar e da Reforma Agrária (COOPERAF), instituído, através da portaria ${ }^{\circ} 204$, de 22 de junho de $2015^{11}$, que visou à estruturação de uma nova política de comercialização para as agriculturas de base familiar, apoiado no fortalecimento de suas organizações econômicas. Logicamente, este processo foi interrompido com a retirada do Governo da Presidenta Dilma, em 2016.

A VISÃo dos GESTORES PÚbLICOS SOBRE O PAPEL DESEMPENHADO PELA Conab na EXeCuÇ̃̃o da PGPM e do PAA no PERíodo de 2003 a 2014

Várias abordagens foram dadas pelos entrevistados em relação ao papel desempenhado pela CONAB quando buscamos aferir o cumprimento de sua missão institucional em relação à garantia de renda ao produtor e promoção da regularidade do abastecimento, mesmo entendendo que as questões, por si só, não são sinônimas de promoção da segurança alimentar e nutricional. Vale lembrar que essa missão foi instituída no bojo da estratégia fome zero, que trouxe consigo uma reestruturação interna, conforme determinação da

${ }^{1}$ A portaria pode ser acessada no site: http://www.mda.gov.br/sitemda/sites/sitemda/files/user__img_24/ Portaria\%20Coperativismo-\%20Cooperaf.pdf. Acesso realizado em 06/12/17.
Portaria Interministerial MAPA/MESA, de abril de $2003^{12}$. De qualquer forma, é inegável a nova atribuição dada, após 2003, como cita a entrevista "3":

[...] e na época, obviamente, que o Graziano, na recomendação, era: vamos recuperar a capacidade da CONAB. A CONAB é... a gente tem até estruturas, desenhos, que a gente fez, a CONAB será a empresa operadora do Fome Zero. Essa era a decisão que foi apresentada para o Lula, e ele queria. E a criação do MESA Ministério Extraordinário da Segurança Alimentar. A ideia era que a CONAB, é... trabalhasse a serviço do MESA...

Portanto, o Governo Lula, por meio da estratégia Fome Zero, determinou à $\mathrm{CONAB}$ um novo papel a cumprir, claramente identificado em promover políticas de abastecimento alimentar, conectando a produção de base familiar com a população mais vulnerável que necessitava de alimentos, tendo o PAA como programa materializador da atribuição, inclusive atuando como mais um instrumento constituidor de estoques públicos de alimentos, junto à PGPM (Entrevistas 1, 3, 5, 9).

No entanto, o programa de Governo também apontava para a necessidade de avançar nas exportações de commodities agrícolas, devendo a CONAB cumprir também este papel, conforme anunciado na "carta ao povo brasileiro" ${ }^{13}$, publicada pelo Presidente Lula em 2002 e seu discurso de posse $^{14}$, em 2003.

Parte dos entrevistados entendeu que as políticas, executadas pela CONAB, nesse período, em especial a PGPM e o PAA, contribuíram para que parte dos agricultores, no Brasil, tivessem suas margens mínimas de renda garantidas (entrevistas 1, 2, 8 e 9), como expressa a entrevista 9, que reconhece a atuação decisiva da CONAB na recuperação ascendente dos preços mínimos de vários produtos, como feijão, arroz, trigo, dentre outros, gerando ganhos e recomposições para parte importante dos agricultores

${ }^{12}$ Portaria Interministerial MAPA/MESA n ${ }^{\circ}$ 183, de 14 de abril de 2003. Segundo Maya Takagi, em sua entrevista para esta pesquisa, ainda na transição do Governo, no final de 2002, houve discussões entre o Ministro José Graziano da Silva e o Presidente Lula sobre a CONAB ser vinculada diretamente ao MESA, fato que não se viabilizou politicamente, ficando o MESA com a estrutura do Comunidade Solidária, tendo a CONAB como braço operacional, mas seguindo vinculada ao MAPA.

${ }^{3}$ A "carta ao povo brasileiro" foi um documento público, assinado pelo Presidente Lula na campanha presidencial, em 22 de junho de 2002. Pode ser acessada http://www.iisg.nl/collections/carta ao povo brasileiro.pdf. Acesso em $25 / 11 / 2017$

${ }^{4} \mathrm{O}$ discurso pode ser acessado http://www.biblioteca.presidencia.gov.br/presidencia/ex-presidentes/luiz-inaciolula-da-silva/discursos/discursos-de-posse/discurso-de-posse-1o-mandato/view. Acesso em 25/11/2017 
tanto do agronegócio, quanto da agricultura familiar, sem no entanto ter a mesma atuação na regulação da oferta de alimentos para o abastecimento interno, conforme citado por um dos entrevistados: "e então, eu acho que em termos de preço, a CONAB foi muito mais efetiva do que em termos de regularidade do abastecimento..."(Entrevista 9).

A sequência de ajustes nos preços mínimos em um conjunto considerável de produtos (50 produtos agropecuários e extrativos), realizados pela CONAB, após 2003, ativaram um conjunto de políticas de fomento da produção neste período, possibilitando o cumprimento de um papel diferente em relação às políticas agrícolas, implementadas na primeira década de vigência da Lei Agrícola de 1991. De forma geral, o realinhamento dos preços mínimos, efetuados no período de 2003 a 2014, foi fundamental para a estruturação de fortes políticas de fomento à produção, especialmente de linhas de créditos e de seguros agrícolas, criados e ampliados tanto para a agricultura familiar (em articulação com a Estratégia Fome Zero e com as políticas de segurança alimentar e nutricional), quanto para o agronegócio, reforçando a consolidação de um padrão de produção de alimentos, pautado por sucessivos ganhos de produtividade, concentrado geograficamente (Sul e Centro Oeste), acessado por um reduzido número de agricultores (familiares ou não), fortemente articulados a um novo padrão de funcionamento do sistema agroalimentar mundial, conforme descrito por Maluf e Speranza $(2013,2014)$. Nessa perspectiva, atuaram, também, os mecanismos da PGPM, em especial os que realizaram a subvenção privada dos processos de comercialização. De acordo com a própria CONAB, as estratégias de realinhamento dos preços mínimos não objetivavam qualquer incentivo à formação de estoques públicos para garantir a regularidade dos preços e da oferta. Essa política pública sempre foi considerada como acessória à política de apoio à produção (CONAB, 2016, p. 14).

É essa perspectiva de estruturação da agricultura brasileira que leva a maioria dos entrevistados a afirmar que as ações executadas pela CONAB, nesse período, atuaram parcialmente na regularidade do abastecimento alimentar, ficando explícitas as diferentes visões existentes dentro do Governo. As perspectivas adotadas em torno do termo "abastecimento", que remontam à reestruturação da política agrícola, implementada na década de 1990, possuem relação direta com a abertura e a estruturação do sistema agroalimentar capitalista e, ao mesmo tempo, colidem com a perspectiva construída pela segurança alimentar e nutricional, que traz como princípios a promoção do direito humano à alimentação adequada e a soberania alimentar. Constata-se que a lei agrícola, de 1991, manteve-se como linha estratégica orientadora das decisões do MAPA e subordinou parte importante das ações da CONAB, mesmo após sua reestruturação em 2003, realizada em alinhamento às políticas de segurança alimentar e nutricional, instituídas pela estratégia Fome Zero.

As opiniões dos entrevistados foram unânimes ao declararem a contrariedade do MAPA e as resistências do Ministério da Fazenda em relação à formação de estoques públicos de alimentos como mecanismo importante de promover a regularidade do abastecimento, mesmo tendo sido constituídos importantes volumes, especialmente durante os Governos Lula. Essas posições ficam explícitas em declarações, como:

[...] então, o Ministério da Agricultura não quer estoque público, o mercado não quer estoque público, o mercado quer manter sobre o seu controle o abastecimento regular, dentro das normas do mercado; e o controle, inclusive, do pico especulativo. Se abre a janela, e ninguém fala mais, hoje, do arroz, do milho, do feijão, exclusivamente, dentro de um país. Os caras olham o mapa inteiro e já sabem onde há uma possível quebra de grãos do arroz tailandês, possível quebra de grão do feijão mexicano, possível quebra de grão do trigo canadense; os caras olham aquilo tudo. E suas estruturas de armazenagem dos grãos, que é possível manter por muito tempo armazenado, os caras fazem o jogo da oferta e da demanda. E muitas vezes, o pico inflacionário não tem nada a ver com ampliação ou diminuição do consumo dentro do Brasil, tem a ver com dinâmica internacional, que só valoriza, ainda mais, a tendência de exportação desses alimentos, porque se transformaram todos em commodities... (Entrevista 1).

[...] olha, eu acho que tiveram momentos pontuais que foram usados, mas não algo estrutural; e, eventualmente, a gente pegou carona no instrumento da PGPM para defender alguns grupos de produtores; então, tinha uma atuação da CONAB a partir de quem liderava ela, da divisão de liderança que tinha dentro dela, que alguns momentos usou a PGPM para defender o produtor de trigo do Rio Grande do Sul, por exemplo. Isso aconteceu, mas não foi... mas não dá para dizer que foi uma política estrutural de defesa da renda do produtor, e muito menos de combate à inflação, ou de garantia de abastecimento 
à população... (Entrevista 2).

[...] a CONAB era um instrumento garantidor de preço na baixa; era sempre assim, a CONAB era um instrumento garantidor da renda, na baixa; então, o Poder Público entrava para garantir renda, para a baixa; era mais este instrumento sempre garantidor de renda, do que uma... um conceito estratégico de abastecimento à população, por conta da oferta de alimento... (Entrevista 10).

As motivações elencadas, que buscam explicar esse posicionamento estratégico de parte do Governo, representado pelo MAPA, durante todo o período estudado, e pelo Ministério da Fazenda, na maior parte dele, mostram posições divergentes entre os entrevistados. Para a maioria deles, a lógica da política agrícola, implementada pelo MAPA, não admitia, em hipótese alguma, a constituição de mecanismos que pudessem provocar algum nível de regulagem ou intervenção nas esferas de atacado e varejo do sistema agroalimentar. Percebe-se que esse é um dos pontos centrais de críticas à política agrícola implementada pelo Governo, durante todo o período estudado, apontadas também por outros estudos, dentre eles, pelo CONSEA (2005) e Maluf e Speranza (2013 e 2014). De maneira geral, como sintetizado na entrevista "2", a formação de estoques e a subvenção da comercialização atuaram para absorver e escoar a produção excedente nas regiões produtoras, e subsidiar a competitividade de alguns grãos em relação aos preços internacionais, possibilitando competitividade ao agronegócio, através de subsídios públicos. É bastante ilustrativa a seguinte declaração:

[...] no âmbito dos dirigentes do Ministério da Agricultura, era piada falar em abastecimento, o papel deles era garantir preço; e se estocasse, precisasse estocar, na hora que eles demandassem o produto, fosse uma demanda do próprio segmento em relação ao produto, para vender mais barato, aí sim entrava a discussão, mas não pensando do ponto de vista da população, como um todo... (Entrevista 5).

Para outros, as motivações constituíam-se em questionar a efetividade da atuação de estoques públicos como um importante mecanismo de regulação do abastecimento. Nesta perspectiva, a compreensão do abastecimento alimentar, passa por concordar que as regras definidas pelo mercado globalizado de alimentos ditam os parâmetros com mais eficiência, garantindo a oferta dos alimentos à população. Fortes também são os argumentos referentes aos elevados custos de aquisição e manutenção de estoques públicos de alimentos, além da necessidade de serem formados em grandes volumes, para terem capacidade de influenciar no mercado. A interpretação da entrevista "4" deixa explícita a visão contrária à formação de estoques, afirmando que os estoques formados no período, não produziram efeitos sobre a inflação dos alimentos, pois o volume foi pequeno e porque o Brasil não é formador de preços. Segundo este entrevistado, os preços são formados em praças internacionais, como Chicago, Londres e Nova Iorque. Ao mesmo tempo, essa visão defende os demais mecanismos da PGPM, alegando que, com os mecanismos de subvenção do escoamento da produção, se garante a renda ao produtor e o abastecimento interno para regiões que apresentam falta do produto. Elementos semelhantes também são constatados no estudo realizado por Schwantes e Bachas (2017), ao analisarem custos sociais e orçamentários das políticas de garantia de preços no Brasil. Esses elementos constituem o núcleo central dos argumentos contrários aos mecanismos de intervenção, através da formação de estoques públicos de alimentos, como exemplificam as seguintes declarações:

[...] olha, não precisa de montanhas de produto. Até porque, com a globalização, e com o mercado aberto, e com os acordos de Mercosul, de... tem menos produto, é que você busca ali. [...] olha, não voltou no Governo do PT; portanto, não vai voltar em outro Governo mais liberal, a formação de estoques em grande volume; porque, qualquer um que for fazer conta, ele vai chegar à conclusão de que não... isso não é bom para o produtor, isso não é bom para o Governo, gasta muito dinheiro... (Entrevista 4).

[...] primeiro, que há uma questão, um aspecto, assim, de ideologia dentro do Governo, daquela história de ser neoliberal, deixa o mercado se virar, entendeu. Além disso, tem a questão fiscal, o pessoal alega que não tem espaço fiscal por conta da crise, e ainda os cortes, e tal; então, não tem dinheiro para fazer; tem orçamento, mas não tem o dinheiro. Entendeu? Então, aí dois aspectos. Então, assim, importante, a gente acha que é. A gente sempre faz nota técnica propondo... defendendo a formação de estoque... Só que... Só que não fica na... assim, isso não depende só da gente... aí depende do lado do Governo, em si, entender, e comprar a briga. Só que a 
gente está observando aí que não... não está caminhando nesse lado não... (Entrevista 6).

Mesmo que essa visão tenha se constituído como hegemônica, especialmente no centro econômico do Governo ao longo das três gestões estudadas, os dados sistematizados pela pesquisa e a metade dos entrevistados, registraram uma pequena inflexão do Governo, especialmente do Ministério da Fazenda, após a crise de 2008, onde o tema da inflação dos alimentos começou a ficar mais presente e a CONAB formou estoques importantes de milho, colocando-os no mercado interno como mecanismo de controle de preços ao consumidor e como instrumento de abastecimento de regiões afetadas pela seca. Nesse aspecto, o segundo Governo Lula (2006 a 2010), foi o período no qual a CONAB formou os maiores volumes de estoques públicos (Entrevistas 1, 5, 8, 9 e 10).

Conforme adverte o entrevistado "5", no período de 2003 a 2010, a CONAB virou uma grande estocadora de grãos. No entanto, não foi unicamente por uma estratégia de armazenagem no intuito de realizar abastecimento alimentar, mas principalmente por pressão do agronegócio no MAPA, que demandavam a intervenção para garantir renda a seus setores. Importantes nesse cenário, também são as afirmações da entrevista " 8 ", onde o entrevistado declara que o milho é um produto chave e um dos que tem o maior lobby de pressão política por meio da bancada ruralista, que tenciona o MAPA, no uso dos instrumentos da PGPM, seja para formar estoque ou apoiar o escoamento, alinhado aos seus interesses econômicos. Em complementação, a entrevista "9" afirma que teve um ano em que a CONAB vendeu, no mercado, um milhão de toneladas de grãos e demonstrou uma enorme capacidade de intervenção. Foi aí que o Ministério da Fazenda percebeu a importância da atuação dos estoques para amenizar a subida dos preços dos alimentos. Porém, esta percepção que se configurou por volta de 2008, não se manteve no período seguinte. O resultado da ausência de uma política de abastecimento foi a presença constante de pressões inflacionárias, puxadas pelos alimentos, no período de 2010 a 2015. O entrevistado ainda segue afirmando que, de forma geral, as vendas dos estoques sempre foram feitas a conta gotas, por ordem do MAPA, não impactando na baixa de preços no mercado, mesmo após ter sido criado o $\mathrm{CIEP}^{15}$, em 2013. Fica

\footnotetext{
${ }^{5}$ Conselho Interministerial de Estoques Públicos de Alimentos (CIEP), criado em 2013, com o objetivo de defini
} as condições para aquisição e liberação de estoques públicos de alimentos. explícito dessa forma, que as formações de estoques públicos, no período, não se constituíram em um instrumento permanente de abastecimento alimentar e muito menos como mais um mecanismo a ser usado no controle da inflação, fortemente influenciada pelo aumento dos preços dos alimentos, especialmente na última gestão federal estudada. Análise semelhante é também apresentada por Maluf e Speranza $(2013,2014)$. Em complemento a essa análise, a entrevista "7" afirma que a ausência de estoques de milho e de feijão contribuíram para a tendência altista dos preços, ocorridos nos anos de 2013, 2014, 2015 e 2016, pois segundo a entrevista, o mercado reage só em saber que o Governo não tem estoques.

Outra questão importante a ser analisada foi referente aos elementos centrais que dirigiram a agenda do MDA, no período formado pelos dois governos Lula. Segundo a entrevista "10", a preocupação central foi em estruturar uma agenda de fomento à produção e garantia de renda à produção de base familiar. Nessa ótica, priorizou-se a estruturação de outros mecanismos de política agrícola, como crédito, seguro agrícola, preços mínimos e assistência técnica, sendo inclusive o PAA, compreendido nessa perspectiva. A lógica da agenda, para combater o pico inflacionário dos alimentos, era ampliar a capacidade de produção, gerar renda e qualidade de vida para a base da agricultura familiar. Somente ao final de 2010, se retomou uma reflexão no MDA e no conjunto das forças da agricultura familiar, sobre o papel e a vinculação integral da CONAB a este setor econômico. Embora as motivações fossem diferentes das apresentadas na transição de Governo, em 2002, e início do Governo Lula, em 2003, o fato da elevação dos preços dos alimentos começar a influenciar fortemente nos índices de inflação, tornando o tema importante na agenda da política econômica, motivou o MDA a discutir a vinculação integral da CONAB à sua estrutura, reconhecendo a importância da instituição como promotora do abastecimento alimentar, completando uma lacuna no conjunto das políticas executadas no período, centradas fortemente no fomento a estruturação produtiva, conforme declara o entrevistado "10":

[...] esse era o tema. Quer dizer, o máximo que nós chegamos, tanto que se re-pautou a ideia de, no próximo Governo, a CONAB vir para o MDA, como um conceito estratégico de abastecimento, que é o que justificava, tu entende? Então, nós tínhamos essa formatação, e faltava uma perna ali: Qual era o instrumento de abastecimento? Era a CONAB, que nós nunca conseguimos chegar perto, não é. 
Tinha uma... uma Diretoria lá, não é, o Silvio e o Intini, mas não... enfim... (Entrevista 10).

Tão fundamental quanto a decisão de alocar recursos financeiros para constituir estoques públicos de alimentos é a estruturação de uma rede de armazenagem pública que crie as condições para esse fim. A flagrante defasagem tecnológica do sistema de armazenagem público, estruturado em décadas anteriores, constitui-se como elemento chave na fragilização da atuação da CONAB. A precarização da rede pública de armazenagem da CONAB é apontada por vários dos entrevistados como um dos elementos centrais para a não constituição de estoques públicos de alimentos num volume maior, mais diversificado, permanentes e com menores custos de carregamento. (Entrevistas 1, 4, 5, 6, 8 e 9)

A síntese das afirmações, realizadas pelo entrevistado "1", não deixam dúvidas, quando declara que não houve modernização do sistema de armazenagem público em relação a década de 1990, provocando uma defasagem tecnológica que causa baixa eficiência, altos custos e perdas, sendo substituída pela iniciativa privada, nas regiões de produção. De acordo com a entrevista "5", por não haver uma política de valorização da rede de armazenamento da CONAB, onde o Governo pudesse assumir o custo de manutenção de toda a rede, foi implementada uma lógica de recuperar somente onde o armazém se viabilizasse economicamente, ficando as velhas estruturas sem modernização, principalmente nas regiões deficitárias de produção, como no nordeste. O cenário pode ser bem caracterizado, a partir da fala do entrevistado "9", que afirma:

[...] eu diria que, mesmo fazendo a reabertura de unidades, em termos numéricos, foi significativo. Mas, em termos de capacidade de armazenagem, muito pequena. Então, o problema é que era uma rede defasada, uma rede inadequada, e que, portanto, ela precisava, efetivamente, de um processo de modernização; e de um repensar, inclusive, de... de instituir novas unidades em lugares estratégicos. Então, o fato é que, por se tratar de uma rede antiga, boa parte dela era armazém geral, não eram silos, e... e isso limitava muito a capacidade operacional do recebimento de volumes, recebimento de cargas, de recebimento e despacho dessa carga. Era um sistema que dependia, que tinha que, necessariamente, chegar, como no caso do milho para o nordeste, toda aquela intervenção que se fez; então, o produto chegava, é... ou a granel, mas tinha... se chegasse a granel, tinha que ser ensacado; e se chegasse a granel, não tinha nenhuma rampa, minimamente, para poder descarregar aquilo, colocar num lugar adequado; ia para o chão, do chão ia... tinha que ter uma trupe de gente para poder ensacar, para poder depois vender $60 \mathrm{~kg}$ por $60 \mathrm{~kg}$. Ou seja, uma rede totalmente defasada. O grande problema, de fato, é que não houve uma modernização; mesmo que em pequenos silos, mas que nós tivéssemos, de fato, uma rede que desse uma possibilidade de armazenar de forma mais adequada; e, ocasionalmente, ela fosse mais ágil, no sentido do recebimento, de fato, dessa carga, desse volume. Então, isso, realmente, eu te diria que era o grande problema da CONAB, ficou muito defasado no tempo... (Entrevistado "9").

De acordo com a entrevistada " 6 ", não houve estruturação da rede de armazenamento da $\mathrm{CONAB}$, pois as políticas agrícolas dos últimos dez anos focaram muito na estruturação da produção e não estruturaram a questão da armazenagem. Tal situação produz um aumento dos custos de escoamento que poderiam ser reduzidos se realizados na entressafra, caso houvesse uma rede de armazéns pulmões, nas zonas produtoras, e uma rede de armazéns de distribuição, nas zonas deficitárias e de consumo.

Mesmo com o lançamento do Plano Nacional de Armazenagem (PNA), pelo Governo Federal, em 2013, ao longo de sua execução o tema não foi enfrentado pela perspectiva de estruturação de instrumentos públicos que pudessem constituir-se como potencial de regulação na esfera do atacado e do varejo no Brasil. Segundo a entrevista " 5 ", no processo de definições de critérios e normas do PNA, as posições do livre mercado prevaleceram. As principais divergências se concentraram nos seguintes pontos: a) taxa de juros preferencial para produtores e suas cooperativas; e, b) taxas de juros para priorização de regiões com estímulos para construção, a partir do mapeamento das deficiências de estocagem. $\mathrm{O}$ resultado final não adotou nenhum dos critérios propostos, abrindo o acesso para qualquer tomador, sem distinção de localização do armazém, podendo ser feito, inclusive, nos portos de exportação. Porém, o mesmo entrevistado relata que, dentro do PNA, ficou definido um conjunto de armazéns públicos que seriam modernizados, bem como um conjunto de novos armazéns a serem construídos, no intuito de cobrir os territórios deficitários de armazenamento, inclusive em regiões nas quais a iniciativa privada não se motivaria a 
construir. Não foi possível identificar, por esta pesquisa, nenhuma ação concreta que tenha sido implementada pelo Governo Federal, de 2013 até o momento, nesta perspectiva.

\section{A gestão e execuÇão da PGPM Pela CONAB no Período de 2003} A 2014

Há um reconhecimento geral da forte recuperação orçamentária e financeira da PGPM no período estudado, em relação aos anos de 1990. Especialmente nos dois Governos Lula (2003 a 2010), ela voltou a cumprir um papel importante na política agrícola, especialmente na região centro-oeste do Brasil. Mais uma vez, se faz referência à importância da recomposição dos preços mínimos realizados no período, especialmente para a manutenção de produções locais que contribuíram para o abastecimento regional, promovidos em grande parte pela agricultura familiar. Porém, de acordo com a leitura de alguns entrevistados, raramente a PGPM atuou como uma política articulada à estratégia Fome Zero e, logicamente, não alinhou-se integralmente às políticas promotoras de segurança alimentar $\mathrm{e}$ nutricional. (Entrevistas 1, 3 e 9)

A estratégia de formação de estoques públicos de alimentos não foi a mais relevante, pois priorizou-se a utilização dos mecanismos de subvenção ao escoamento da produção. A PGPM teve uma atuação pontual e segmentada, não se constituiu numa política estrutural de formação de estoques públicos, nem na defesa da renda da maioria dos agricultores e, muito menos, no combate à inflação ou na garantia do abastecimento à população (Entrevistas, 2 e 9). As avaliações em torno da atuação dos mecanismos da PGPM, endossam as análises e os estudos realizados, ao longo de sua existência, que marcam sua história desde a criação, em 1943. A análise histórica do abastecimento no Brasil e a execução da PGPM, até 2002, registra com abundância de evidências, os dilemas encontrados pela PGPM em cumprir plenamente o que é declarado em suas normas e objetivos definidos desde sua criação. (ALMEIDA, 2014; BELIK, 2017; DELGADO 1978,1995, 2005; LINHARES, 1979)

Outra constatação é que a constituição dos estoques públicos de alimentos, formados nesse período, não estavam orientados estrategicamente para enfrentar a alta de preços dos alimentos e pouco atuaram na regulação da oferta aos consumidores. Fato que contribuiu para o aumento da inflação, causada por especulação do mercado, por quebras de produção e/ou por problemas climáticos, como por exemplo, ocorrido com o feijão nos anos de 2013 a 2016. Quando houve inflação dos alimentos, os estoques já estavam todos vendidos, fragilizando a ação do Estado. (Entrevistas 1 e 2)

Evitando cair num falso debate sobre qual mecanismo da PGPM é mais adequado ou qual é o melhor, a preocupação central de nossa análise é perceber com qual finalidade a política como um todo, foi executada, realizando o estudo a partir das lógicas que motivaram a constituição e a liberação dos estoques públicos de alimentos, nesse período. Foram as opiniões sobre as finalidades da utilização dos mecanismos da PGPM que materializaram as diferentes concepções e que orientaram sua utilização no período.

Em relação aos mecanismos de subvenção da comercialização, foram apontadas diversas finalidades que justificaram a utilização dos mesmos durante o período. Algumas opiniões reconhecem a importância do instrumento para o abastecimento interno, utilizando-os de forma combinada com a formação de estoques públicos, propiciando oferta de produtos, como arroz, milho e trigo, em regiões deficitárias na produção desses alimentos, como, por exemplo, o nordeste brasileiro (Entrevista 1). Outros, agregam à finalidade sua adequação para garantir renda aos produtores e equiparar os preços internos aos dos produtos importados (Entrevista 4). Porém, algumas críticas também são explicitadas, evidenciando uma opinião sobre a finalidade dos mecanismos de subvenção da comercialização, conhecidos também, após a reestruturação da década de 1990, como mecanismos de mercado. Aponta-se uma concentração na utilização da PGPM, em especial dos mecanismos de subvenção, na região centro oeste, estando essa fortemente articulada à política de exportação de commodities, em especial soja e milho (Entrevista "8"). Em posição contrária ao entrevistado "4", são apresentados problemas sérios de transparência no processo de garantia de renda aos agricultores, quando alguns dos mecanismos de mercado são acessados por terceiros que necessitam comprovar o pagamento do preço mínimo aos agricultores, retendo parte do valor indevidamente. Outro elemento diz respeito a serem recursos, que, quando acessados por seus tomadores, não entram no abatimento do imposto de renda, pois são subsídios públicos, sendo mais um elemento indutor de concentração de acesso para alguns produtores e um pequeno grupo de grandes agroindústrias e empresas comercializadoras. Assim sendo, é emblemática a afirmação da entrevista " 5 ": 
[...] há uma concentração muito grande, eu lembro que num determinado ano, a Família Maggi pegou 23 milhões de reais só em subsídio; e o subsídio público ele é isento de imposto de renda; então, você tem um outro problema. Quando é pessoa jurídica isso tem um peso maior; por exemplo, digamos, que você teve um custo de produção de... é, para milho, de 30 reais a saca, o preço de venda é 25 , você teve um prejuízo de 5. Digamos que o Governo te dê um subsídio de 5 reais por saca, ou 6 reais por saca, ou 7 reais por saca, isto não entra como valor da venda, isso entra como isento do imposto de renda, com uma conta subsídio; e, aí, oficialmente, aquela empresa, ela teve um prejuízo de 5, mesmo tendo zero de prejuízo, porque ela recebeu 5 , ou 6 , ou 7 , ou 10 , digamos, do Governo..." "...Subsídio público é isento de imposto. Então, você tem uma concentração; então, os mecanismos de incentivo privado não funcionaram; principalmente, PEPO, PREPO, essas coisas todas; há um desvio muito grande, uma concentração muito grande na mão desse setor... (Entrevista 5).

Embora se reconheça o papel positivo dos mecanismos de subvenção da comercialização por contribuírem no escoamento e oferta de alimentos em todo o território nacional, e de que são mecanismos menos custosos para os cofres públicos, como constatado por Schwantes e Bacha (2017), de forma geral, mantiveram-se atrelados ao fortalecimento do padrão produtivo do agronegócio brasileiro, completamente integrado de forma subordinada às cadeias agroalimentares internacionais, apresentando concentração de acesso a esses recursos, por um pequeno grupo de processadores e comerciantes, mantendo e aprofundando o poder de especulação e controle dos preços pelo mercado privado de alimentos.

No que se refere à destinação dos estoques, formados pela PGPM, além de ficar evidente sua utilização descontinuada e em pequenos volumes, não se constituiu como um instrumento efetivo de estabilização dos preços e, muito menos, de promoção do abastecimento alimentar, na perspectiva do direito humano à alimentação e da soberania alimentar. No entanto, a execução dos programas de abastecimento social da CONAB, operados através dos estoques formados pela PGPM e PAA, conformaram importante ação para amenizar a escassez de milho para os pequenos e médios criadores do nordeste brasileiro, durante os anos mais críticos da seca que assolou aquele território, cumprindo um papel importante para a segurança alimentar e nutricional daquela população. Na mesma perspectiva foram importantes outras ações de assistência alimentar, como o programa de distribuição de cestas de alimentos para populações vulneráveis, para atingidos por catástrofes ambientais e para doações internacionais, articuladas a partir de uma agenda pró-ativa de cooperação internacional, desenvolvida, fortemente no Brasil, especialmente nas duas gestões do Presidente Lula. Conforme também destacado na pesquisa realizada por Almeida (2014), a CONAB foi fundamental para viabilizar as ações articuladas no bojo da estratégia Fome Zero e do Plano Brasil Sem Miséria.

\section{A gestão e execução do PAA Pela CONAB no Período de 2003} A 2014

O PAA, quando concebido, em 2002/2003, já nasce com um forte viés de tornar-se uma alternativa de comercialização para a agricultura familiar, formando estoques públicos conectados às políticas de abastecimento social, como por exemplo, a distribuição emergencial de cestas de alimentos realizada pela CONAB. Embora esse não fosse o único enfoque definido para o PAA na sua criação, conforme explicitado por Delgado (2005), acabou por dominar sua crescente evolução, de 2003 a 2012, sofrendo forte desaceleração nos anos posteriores, chegando praticamente à extinção, em 2017.

A gestão dos estoques, formados através do PAA, mesmo sendo menores que os formados pela PGPM, diferentemente desta, tiveram um completo alinhamento com as políticas de segurança alimentar e nutricional, coordenadas pelo MDS, em articulação com o MDA. (Entrevistas 3 e 9)

O PAA também é considerado um programa ágil, eficiente, de gestão fácil, garantidor de renda ao produtor e altamente conectado aos programas de abastecimento social, alinhado com a estratégia Fome Zero, com a segurança alimentar e nutricional e com o direito humano à alimentação. Inspirado naquilo que a PGPM pouco realizava, constituiu-se numa referência positiva para a estruturação de uma política de abastecimento alimentar vinculando a produção da agricultura familiar e uma forte política social estruturadora de uma rede de proteção e promoção social no país. (Entrevistas 1 e 2)

A síntese de opiniões sobre o papel desempenhado pelo PAA, enquanto ação estruturadora de uma outra perspectiva de produção agrícola, fortemente articulada a circuitos locais de produção e consumo, descentralizado e atuante em todo o território nacional, com forte valorização da cultura e da diversidade alimentar, gerador de renda e apoiador de processos produtivos saudáveis, pautados pela agroecologia, e, ao mesmo tempo, conectado em 
circuitos de abastecimento social, é fartamente identificado em inúmeras pesquisas e análises já realizadas sobre o programa, como por exemplo: Consea (2005); Delgado (2005); Fao (2014); Grisa e Porto (2015); Menezes, Porto e Grisa (2015).

Neste período, intervenções importantes foram realizadas pelo PAA. Como referências, podem ser citadas as aquisições de feijão, nos três primeiros anos, em Rondônia, garantindo renda para os agricultores e escoamento da produção por intermédio de cestas de alimentos, venda em balcão, tendo funcionamento parecido com a AGF da PGPM. Assim como foram significativas as intervenções na castanha de caju com venda deste estoque público para as pequenas processadoras. Houve, também, uma atuação forte do PAA na produção de leite, garantido o funcionamento das cooperativas da agricultura familiar, sobretudo do Rio Grande do Sul, através da transformação em leite em pó e sua distribuição nas ações de abastecimento social (Entrevistas 9 e 10).

De acordo com algumas entrevistas, para o MDA, o PAA sempre foi compreendido como um instrumento fundamentalmente de desenvolvimento territorial e garantidor de renda aos agricultores familiares, como, de certa forma, ficou também compreendida toda a agenda das compras públicas, envolvendo o PNAE e o abastecimento do mercado institucional mais recentemente. (Entrevista 10)

Porém, para o CONSEA (2005), o PAA apresentava-se como uma iniciativa com maior potencial, transpondo as funções de apenas garantir renda e ser um canal de comercialização para a agricultura familiar conectado a uma política de assistência alimentar. Para o CONSEA, o PAA sintetiza um programa que incorporou os princípios do direito humano à alimentação e da soberania alimentar, sendo apontado como um potencial programa estruturador de uma nova política nacional de abastecimento alimentar.

$\mathrm{Na}$ análise realizada sobre a execução do PAA e nas entrevistas realizadas, aparecem dois elementos importantes para nossas sugestões de aperfeiçoamento das políticas públicas de abastecimento alimentar.

O primeiro diz respeito a alguns mecanismos estratégicos do PAA que foram interrompidos, já nos primeiros anos de sua execução, acarretando uma enorme perda estratégica para o programa, como a modalidade Compra Antecipada da Agricultura Familiar (CAAF). A manifestação, feita pelo entrevistado "9", e as ponderações, realizadas por Delgado (2005), revelam alguns desafios que permanecem no horizonte, dentro de uma agenda de construção de uma nova política de abastecimento para o Brasil:

[...] bom, eu acho que, em primeiro lugar, uma das grandes modalidades que foi morta na sua gênese, foi a Compra Antecipada, na lógica do fomento à produção. Ou seja, uma linha de fomento à produção não bancarizada e não creditícia; que, infelizmente, nós não tivemos tempo para desenvolver da forma como deveria, ao meu ver, assegurando assistência técnica, assegurando uma outra complementariedade de ação..." “...Ele era mais do que o EGF, porque tu liberava o recurso como custeio..." “... A Compra Antecipada, ela tinha a lógica realmente de fomento, ela tinha um VBC, ela tinha uma relação de... então, nós criamos lá um valor básico de custeio para cada produto, tinha uma relação de pagamento em produto, dava a possibilidade de pagar em produto ou pagar em financeiro a escolha das organizações. Então, para mim, uma das grandes modalidades, uma das grandes inovações, foi essa primeira modalidade; que, infelizmente, por uma disputa política interna, da Fazenda e, sobretudo, junto com o MDA, não é; com o receio que o MDA passou a ter de que isso poderia competir com... com o Pronaf, vamos dizer assim; o que, de alguma forma, poderia colocar em cheque, ou enfraquecer o Pronaf. E, fortalecendo a CONAB, como a CONAB não era um ente vinculado ao MDA, então podia fortalecer o Ministério da Agricultura, ou seja, uma visão fraca, uma visão míope, no sentido de que, ao contrário, que poderia ter colocado, como fez o MDS, colocando a CONAB a serviço do MDA, não é; mas não conseguiram fazer essa ponte. Entendeu?... (Entrevista 9).

Esta oportunidade constituída pelo PAA-CAAF, interrompida em 2004, que possibilitaria às organizações de produção de base familiar acessar recursos por fora das normas bancarizadas do crédito, constitui a alternativa para um conjunto considerável de críticas ao Pronaf realizadas ao longo dos últimos anos, como apresentado por Capellesso (2016).

O segundo elemento importante a ser considerado numa perspectiva de retomada da agenda de políticas promotoras de segurança alimentar e nutricional, diz respeito aos canais de destino dos alimentos operados via um programa como o PAA. De acordo com um dos entrevistados, o PAA ficou limitado quanto às estratégias de destino dos alimentos, vinculando-se, apenas, aos programas de abastecimento assistenciais, tendo sua execução diminuída no último período, especialmente pós 2012. A ausência de 
uma política nacional de abastecimento articulada a segurança alimentar e nutricional fez com que as políticas sociais promotoras do acesso aos alimentos, especialmente as executadas em períodos de crises econômicas, se reduzissem a transferência de renda, sem interferir na estrutura de atacado e varejo do país. Perdeu o potencial que poderia ser desenvolvido, numa outra estratégia de proteção alimentar da população, podendo ser suporte a estruturação de um outro circuito de atacado e varejo, que viabilizasse o acesso aos alimentos de formas diretas à população. Essa posição fica explícita, a partir das seguintes afirmações:

[...] então, quando fazíamos uma compra direta, que podia socorrer a renda do produtor, podia socorrer um excesso de produção, por exemplo, o canal de distribuição podia ser muito bem uma rede de proteção alimentar, que a gente nunca pensou nisso, nós pensamos em proteção social, com direitos sociais e serviços públicos educação, saúde -, serviço público; mas não falamos num sistema de proteção alimentar, e aí perdeu a... perdeu o sentido de manter essas operações que socorriam aqui, sendo que o destino... Então, eu acho que a gente funcionou muito movidos por uma conjuntura de disponibilidade orçamentária, então: Quanto precisa? 100 milhões para fazer leite em pó? - 100 milhões para fazer leite em pó. E o destino se perdeu. Então, eu imagino que um conceito que a gente não desempenhou, nesse período nosso, embora tenhamos evoluído muito na segurança alimentar e nutricional, do direito humano à alimentação, não é; isso evoluiu muito, um sistema de segurança alimentar, nós não discutimos um sistema de proteção alimentar.. (Entrevista 1).

\section{ConClusão}

No período estudado, a CONAB foi estruturada e disputada para cumprir dois papéis, muitas vezes paralelos e conflitantes, embora oficialmente declarados oficialmente como complementares: a) contribuir para alavancar o fortalecimento do agronegócio e a exportação de commodities e, b) ser o órgão operador de um dos principais programas de segurança alimentar e nutricional, criados no período, o PAA.

A partir das evidências analisadas por este estudo, é possível concluir que, mesmo tendo a companhia definido uma nova missão a partir da estratégia Fome Zero em 2003, pautada na promoção da segurança alimentar e nutricional, a lógica de execução de sua principal política, a
PGPM, manteve os fundamentos e funções desempenhados a partir da abertura dos mercados agroalimentares implementada, no Brasil, a partir dos anos 1990. A formação dos estoques públicos de alimentos, constituídos pela PGPM, bem como seus mecanismos de subvenção do escoamento da produção, submeteram-se, prioritariamente, a lógicas de garantia de renda para parte dos agricultores brasileiros e, via de regra, ficaram subordinados aos interesses dos diversos setores do sistema agroalimentar, formado também, por industriais, atacadistas e comerciantes, fortemente articulados às trades internacionais. Essa lógica contribuiu para o avanço e a consolidação do modelo hegemônico de agricultura, denominado como agronegócio. Tal perspectiva também impediu que se utilizassem, de maneira mais sistemática, os mecanismos de formação de estoques reguladores e estratégicos, delegando ao mercado privado o papel e a função de assegurar a disponibilidade dos alimentos e atribuir preços aos consumidores.

Também é possível concluir que o nível de formação de estoques públicos de alimentos ou, mais recentemente, a inexistência deles, mostrouse limitado e insuficiente para dotar o Brasil de melhores mecanismos de resistência e enfrentamento de crises de abastecimento, permanecendo o país vulnerável em sua estratégia de assegurar o abastecimento e regular o preço do mercado interno de alimentos, limitando sua atuação as lógicas de assistência alimentar e fragilizando a promoção do direito humano à alimentação e à soberania alimentar, preconizados como princípios orientadores do Sistema Nacional de Segurança Alimentar e Nutricional (SISAN), a serem garantidos pelo Estado à toda a população.

No entanto, mesmo mantendo a lógica de consolidação e ampliação do modelo agroexportador, criou-se espaços para também avançar num conjunto de ações estimuladoras de outras perspectivas de promoção de sistemas agroalimentares, alinhados aos princípios do direito humano à alimentação e da soberania alimentar, institucionalizados, nesse período, através de leis, planos e programas.

A decisão política, expressa pela estratégia Fome Zero, e mantida nos planos Brasil Sem Miséria e de Segurança Alimentar e Nutricional, criando o Programa de aquisição de alimentos (PAA), executado pela $\mathrm{CONAB}$, incorporou as agriculturas de base familiar em novos circuitos de comercialização e abastecimento, significando um importante avanço que marca o papel diferenciado, exercido pela CONAB. Embora esta perspectiva tenha sido executada numa condição subalterna em relação às políticas de 
fomento ao Agronegócio, o conjunto de programas e ações desenvolvidos sob a agenda alargada da Segurança Alimentar e Nutricional, que articularam a CONAB a vários órgãos federais, estaduais, municipais e organizações da sociedade civil, contribuiu para o fortalecimento de centenas de iniciativas econômicas e sociais que adotaram outras perspectivas que orientaram novos modos de produzir e consumir alimentos. Estas iniciativas constituem-se como referências para a estruturação de um novo ciclo de políticas públicas de abastecimento alimentar pautados pelos princípios do direito humano a alimentação adequada e pela soberania alimentar.

Em relação à formação dos estoques públicos de alimentos, formados pela PGPM e pelo PAA, constatamos diferenças entre ambos, em relação a função e o papel desempenhados pelos estoques.

$\mathrm{Na}$ PGPM, os reduzidos estoques formados ficaram subordinados ao papel de contribuir com o fortalecimento, mesmo que pontual, do modelo agroexportador, sendo constituídos, na maioria das vezes, por pressão de setores do próprio agronegócio brasileiro, cumprindo um papel insuficiente na estabilização da oferta e dos preços ao consumidor. Ao mesmo tempo, cumpriram um papel importante no suporte às políticas de assistência alimentar e de atuação em períodos de crises ambientais, como as frequentes secas, especialmente as ocorridas no semiárido brasileiro.

Já o PAA cumpriu um papel de destaque nas políticas de segurança alimentar e nutricional desenvolvidas no período. Teve atuação forte, rápida e eficiente no combate à fome, atuando em complementação com os demais instrumentos criados. Seus estoques, embora formados em menor volume, quando comparados com os da PGPM, tiveram também papel central no conjunto das intervenções realizadas no período, cumprindo um papel estruturador às organizações da agricultura familiar e, ao mesmo tempo, deu suporte aos programas de abastecimento social, desenvolvidos pela CONAB em articulação com um conjunto de outros ministérios, governos estaduais e municipais. Porém, por mais inovador que possa ter sido o PAA, ficou limitado a ser um fornecedor de alimentos para as políticas de assistência alimentar, sendo pouco articulado a outros circuitos alimentares que provocassem reestruturação do sistema agroalimentar hegemônico. Embora o PAA tenha em sua gênese, uma profunda identificação com os princípios do direito à alimentação e da soberania alimentar, foi pouco utilizado para a estruturação de circuitos alimentares privados, alinhados com estes princípios. Esse é um potencial atribuído ao PAA, no qual constatamos, no decorrer do estudo, que não foi priorizado, sendo inclusive desativado modalidades que mais dialogavam com estas perspectivas.

As evidências também apontam para a inexistência de uma política nacional de abastecimento que supere a transferência de renda como mecanismo principal de acesso aos alimentos. Porém, não nos referimos a qualquer política de abastecimento. Uma nova política de abastecimento deve constituir um dos pilares estruturadores de outra proposta de desenvolvimento econômico e social para o Brasil, que tenha, na base de suas motivações, o objetivo de acabar com a desigualdade social e econômica no país. Em todos os períodos históricos estudados, as políticas de abastecimento adotadas (ou a falta delas), estão intimamente relacionadas às perspectivas que dirigem a proposta hegemônica de desenvolvimento econômico e social de nossa sociedade. Garantir o direito à alimentação e promover a soberania alimentar são ações que exigem políticas públicas que regulem as esferas do sistema agroalimentar, devendo ficar subordinadas ao controle e aos interesses públicos da maioria da sociedade.

Portanto, a estruturação de circuitos próprios de produção, circulação e consumo, que conectem as produções de base familiar ao conjunto dos trabalhadores brasileiros, parece ser um imperativo para uma nova proposta a ser implantada no Brasil. Nessa perspectiva, a formação de estoques públicos de alimentos ganha uma dimensão estratégica, como, claramente foi proposto por vários entrevistados nesta pesquisa.

Iniciativas que dialogam com essa perspectiva já se materializam em diversos pontos do Brasil. A estruturação de novos circuitos alimentares, a partir das centenas de redes de produção e comercialização, que aproximam a produção do consumo e estabelecem outros valores e princípios que mediam a relação entre produtor e consumidor, apresenta-se como um caminho a ser intensificado. Ações desenvolvidas, a partir da consolidação de feiras livres, de iniciativas vinculadas ao fortalecimento da agroecologia, baseadas numa relação que aproxima camponeses e trabalhadores urbanos, como apresentado pelo programa camponês do Movimento dos Pequenos Agricultores (MPA), já são concretas e demandam novas políticas públicas, que rompam com as lógicas que tentam compensar a exclusão e a exploração produzidas pelo sistema agroalimentar hegemônico.

Nessa perspectiva, seguem, na pauta do dia: a) o acesso à terra, suficiente para promover um processo de produção desconcentrado e pautado pela produção saudável de alimentos; b) implantação de uma política 
agroindustrial e sanitária desconcentrada, pautada em empreendimentos de pequeno e médio porte; c) uma nova lógica de financiamento do processo produtivo, de processamento e de comercialização, comprometida em alavancar uma perspectiva de desenvolvimento que respeite o direito humano à alimentação e à soberania alimentar; d) novos circuitos alimentares que reestruturem as esferas de atacado e varejo do sistema agroalimentar, com participação ativa do Estado, sob forte controle da sociedade, estruturando um sistema de proteção alimentar. Nessa agenda, compreende-se também: a) o realinhamento da $\mathrm{CONAB}$, com a estruturação de uma rede de armazenagem que viabilize uma gestão eficiente de estoques públicos e privados de alimentos, subordinados ao controle social; b) a nacionalização das CEASAs (centrais de abastecimento) e recriação de um sistema nacional de abastecimento que redefina seu papel estratégico no abastecimento de frutas, legumes e verduras no país.

Essas perspectivas não se materializam sem inflexões importantes também no sistema agroalimentar mundial. Portanto, as pautas já estabelecidas por alguns órgãos multilaterais internacionais são de fundamental importância para a construção de um outro caminho para o sistema agroalimentar mundial. As deliberações do Conselho Mundial de Segurança Alimentar da ONU (CMSA) e o conjunto de planos e metas já estabelecidos no continente latino americano, através, especialmente, da Comunidade dos Estados Latino-Americanos e Caribenhos (CELAC), apontam para a necessária transparência das informações sobre os estoques privados do mundo e o controle dos capitais especulativos nos alimentos. Apontam também, para a necessidade dos países adotarem políticas que garantam o direito dos povos em definir suas próprias políticas e estratégias sustentáveis de produção, distribuição e consumo de alimentos, que garantam o direito à alimentação a toda a população, com base na pequena e média produção, respeitando suas próprias culturas e a diversidade dos modos camponeses de produção, de comercialização e de gestão, nos quais a mulheres e jovens desempenham um papel fundamental. Nesta perspectiva, deverão ser criados novos mecanismos locais e regionais que promovam resiliências aos devaneios do capital, como por exemplo, a constituição de estoques públicos de alimentos em nível nacional e regional no continente, dotando o território de melhores mecanismos de enfrentamento da fome, da pobreza e de proteção de seus povos. Para enfrentar este desafio, não bastará, apenas, uma decisão de governo, mas um novo pacto com a sociedade brasileira e latino-americana.

\section{REFERÊNCIAS}

ALADI; FAO. Desarrollo del comercio intrarregional de alimentos y fortalecimiento de la seguridad alimentaria en América Latina y el Caribe. Santiago/Chile, 2015.

ALMEIDA, A, M. A Política de Garantia de Preços Mínimos - PGPM e a atuação da Companhia Nacional de Abastecimento - CONAB -, no período após a abertura comercial: mudança institucional e novos instrumentos. 2014.206p. Tese de doutoramento. ESALQ/USP. Piracicaba/ SP, 2014.

BELIK, W.; CUNHA, A.R.A.A. A formação de estoques reguladores de grãos no Brasil e a Política de Segurança Alimentar. Artigo apresentado no $55^{\circ}$ Congresso da Sociedade Brasileira de Economia, Administração e Sociologia Rural. Santa Maria/RS. UFSM, 30/jul a 03/ago, 2017.

CAPELLESSO, A. J.; Crédito e seguro da agricultura familiar: políticas públicas de apoio à sustentabilidade ou de subsídio a sistemas produtivos de baixa eficiência? 2016. 357p. Tese submetida ao Programa de Pós-Graduação em Agroecossistemas da Universidade Federal de Santa Catarina para a obtenção do Grau de Doutor em Agroecossistemas. Ufsc, Florianópolis/SC, 2016.

COMUNIDAD DE ESTADOS LATINOAMERICANOS Y CARIBEÑOS (CELAC). Plan para la seguridad alimentaria, nutrición y erradicación del hambre de la celac, 2025. Santiago/Chile, 2014.

CONSELHO NACIONAL DE SEGURANÇA ALIMENTAR E NUTRICIONAL - CONSEA. Recomendações para a formulação e implementação de uma Política Nacional de Abastecimento Alimentar (PNAA) baseada no enfoque da segurança alimentar e nutricional (SAN). Brasília, DF. Recomendação n 13, 2005.

DELGADO, C. G. Uma metodologia para determinação de preços mínimos. CFP, 1978. 92 p. (Coleção Análise e Pesquisa, 3). Brasília/DF, 1978. 
DELGADO, G. C.; Estoques Governamentais de Alimentos e Preços Públicos (Relatório de Avaliação do Sistema). Texto para discussão n ${ }^{\circ} 395$, IPEA. Brasília, DF, dezembro de 1995.

DELGADO, G. C.; CONCEIÇÃO, J.C.P.R. Políticas de preços agrícolas e estoques de alimentos: origens, situação atual e perspectivas. REVISTA PARANAENSE DE DESENVOLVIMENTO, n.108, p.25-32, jan./jun. 2005. Curitiba/PR, 2005.

DELGADO, G. C.; CONCEIÇÃO, J.C.P.R.; OLIVEIRA, J.J de. Avaliação do programa de aquisição de alimentos (Paa). Texto para discussão $\mathrm{n}^{\circ}$ 1145, IPEA. Brasília, DF, dezembro de 2005.

FAO. 2014a. O estado da segurança alimentar e nutricional no Brasil: um retrato multidimensional. Relatório 2014. FAO, Brasília/ DF, 2014.

Las compras públicas a la agricultura familiar y la seguridad alimentaria y nutricional en América Latina y el Caribe: Lecciones aprendidas y experiencias. Santiago/Chile, 2015.

GRISA, C; PORTO, S. Políticas públicas de desenvolvimento rural no Brasil. Organizadores Catia Grisa [e] Sergio Schneider. - Porto Alegre: Editora da UFRGS, 2015.

LINHARES, M. Y. L; SILVA, F. C.T. História política do abastecimento (1918-1974). 240 p. (Estudos sobre o desenvolvimento agrícola, v. 6). BINAGRI, Brasília/DF, 1979.

MALUF, R. S. J.; SPERANZA, J. S. Volatilidade dos preços internacionais e inflação de alimentos no Brasil: fatores determinantes e repercussões na segurança alimentar e nutricional. MDS/Secretaria Nacional de Segurança Alimentar e Nutricional. Brasília/ DF, 2013.

MALUF, R. S. J.; SPERANZA, J. S. Preços dos alimentos, modelos de agricultura e abastecimento alimentar no Brasil: os casos da soja e do feijão. Centro de Referência em Segurança Alimentar e Nutricional - CERESAN/CPDA/UFRJ. Observatório de Políticas Públicas para a
Agricultura. Relatório Técnico 7. Rio de Janeiro/RJ, abril, 2014.

MENEZES, F.A.F.; PORTO, S.; GRISA, C. Abastecimento Alimentar e Compras Públicas no Brasil: um resgate histórico. Centro de Excelência contra a Fome - Série Políticas Sociais e de Alimentação; 2015. Disponível em: file:///C:/Users/Lenovo/Downloads/Estudo1_Historico_lowres.pdf. Acesso em 25, abr. 2018.

SCHWANTES, F.; BACHA, C.J.C. Custos sociais e orçamentários das políticas de garantia de preços no Brasil - estudo dos casos de arroz e milho. Revista de Economia e Sociologia Rural, vol. 55, n² 2, Apr/Jun. 2017. Brasília/DF, 2017. 